\title{
The European phenology network
}

Citation for published version (APA):

van Vliet, A. J. H., de Groot, R. S., Bellens, Y., Braun, P., Bruegger, R., Bruns, E., Clevers, J., Estreguil, C., Flechsig, M., Jeanneret, F., Maggi, M., Martens, P., Menne, B., Menzel, A., \& Sparks, T. (2003). The European phenology network. International Journal of Biometeorology, 47(4), 202-12. https://doi.org/10.1007/s00484-003-0174-2

Document status and date:

Published: 01/08/2003

DOI:

10.1007/s00484-003-0174-2

Document Version:

Publisher's PDF, also known as Version of record

Document license:

Taverne

Please check the document version of this publication:

- A submitted manuscript is the version of the article upon submission and before peer-review. There can be important differences between the submitted version and the official published version of record.

People interested in the research are advised to contact the author for the final version of the publication, or visit the DOI to the publisher's website.

- The final author version and the galley proof are versions of the publication after peer review.

- The final published version features the final layout of the paper including the volume, issue and page numbers.

Link to publication

\footnotetext{
General rights rights.

- You may freely distribute the URL identifying the publication in the public portal. please follow below link for the End User Agreement:

www.umlib.nl/taverne-license

Take down policy

If you believe that this document breaches copyright please contact us at:

repository@maastrichtuniversity.nl

providing details and we will investigate your claim.
}

Copyright and moral rights for the publications made accessible in the public portal are retained by the authors and/or other copyright owners and it is a condition of accessing publications that users recognise and abide by the legal requirements associated with these

- Users may download and print one copy of any publication from the public portal for the purpose of private study or research.

- You may not further distribute the material or use it for any profit-making activity or commercial gain

If the publication is distributed under the terms of Article $25 \mathrm{fa}$ of the Dutch Copyright Act, indicated by the "Taverne" license above, 


\author{
Arnold J. H. van Vliet • Rudolf S. de Groot • \\ Yvette Bellens • Peter Braun • Robert Bruegger • \\ Ekko Bruns · Jan Clevers • Christine Estreguil • \\ Michael Flechsig • François Jeanneret • Marta Maggi • \\ Pim Martens • Bettina Menne • Annette Menzel • \\ Tim Sparks
}

\title{
The European Phenology Network
}

Received: 4 July 2002 / Accepted: 24 February 2003 / Published online: 7 May 2003

(C) ISB 2003

Prepared in conjunction with the International Conference "The times they are a-changin". Climate change, phenological responses and their consequences for biodiversity, agriculture, forestry and human health, held in Wageningen, The Netherlands, 5-7 December 2001

A. J. H. van Vliet $(\bowtie) \cdot$ R. S. de Groot

Environmental Systems Analysis Group, Wageningen University, P.O. Box 8080, 6700 DD, Wageningen, The Netherlands

e-mail: arnold.vanvliet@wur.nl

Fax: +31 317484839

Y. Bellens

SME-Milieuadviseurs (GLOBE-The Netherlands), The Netherlands

P. Braun

Department of Agricultural Sciences,

Royal Veterinary and Agricultural University, Denmark

R. Bruegger · F. Jeanneret

Institute of Geography, University of Berne, Switzerland

E. Bruns

German Weather Service, Germany

J. Clevers

Centre for Geoinformation, Wageningen University,

The Netherlands

\section{Estreguil · M. Maggi}

Institute for Environment and Sustainability,

Joint Research Centre of the European Commission, Italy

M. Flechsig

Department of Data and Computation,

Potsdam Institute for Climate Impact Research, Germany

P. Martens

International Centre for Integrative Studies, The Netherlands

B. Menne

World Health Organisation, Italy

A. Menzel

Lehrstuhl fuer Bioklimatologie,

Technical University Munich, Germany

T. Sparks

Centre for Ecology and Hydrology Monks Wood, United Kingdom
Abstract The analysis of changes in the timing of life cycle-events of organisms (phenology) has been able to contribute significantly to the assessment of potential impacts of climate change on ecology. These phenological responses of species to changes in climate are likely to have significant relevance for socio-economic issues such as agriculture, forestry and human health and have proven able to play a role in raising environmental awareness and education on climate change. This paper presents the European Phenology Network (EPN), which aims to increase the efficiency, added value and use of phenological monitoring and research, and to promote the practical use of phenological data in assessing the impact of global (climate) change and possible adaptation measures. The paper demonstrates that many disciplines have to deal with changes in the timing of life-cycle events in response to climate change and that many different user groups are involved. Furthermore, it shows how EPN addresses issues such as (1) raising public awareness and education, (2) the integration and cooperation of existing observing systems, (3) integration and access to phenological information and (4) communication.

Keywords Climate change - Ecology $\cdot$ Agriculture · Human health · Forestry · Communication

\section{Introduction}

During the last ten years there has been a significant increase in the interest in phenology, the study of the timing of life-cycle events of organisms. This is partly due to clearly visible changes in the start of flowering, leaf unfolding and bird migration in many parts of the world have been noted and interpreted in the context of climate change (see next section). Scientists have been able to record these changes, as many long-term monitoring networks exist. The great interest in phenology is also because of the attention paid by the media on a 
regular basis ${ }^{1}$, which has led to large numbers of people participating in phenological monitoring programmes.

Phenological changes are relevant for a large number of disciplines ranging from biodiversity, agriculture and forestry, to human health. Consequently thousands of people are involved. Communication and co-operation, however, are often lacking among the many stakeholders. Therefore, the European Phenology Network (EPN) has been set up to increase the efficiency, added value and use of phenological monitoring and research, and to promote the practical use of phenological data in European member states in assessing the impact of global (climate) change and possible adaptation measures. In this paper, we outline the activities and scope of EPN.

\section{Climate change and phenology}

Nowadays it is widely accepted that the global and regional climate is changing, partly in response to human activities. The Third Assessment Report of the Intergovernmental Panel on Climate Change (IPCC) provided an overview of the changes that have occurred (IPCC 2001). During the 20th century, the increase in temperature was $0.6 \pm 0.2{ }^{\circ} \mathrm{C}$. On average, the daily minimum air temperature over land increased by about $0.2{ }^{\circ} \mathrm{C} /$ decade between 1950 and 1993. This is about twice the rate of increase in daily maximum air temperatures $\left(0.1{ }^{\circ} \mathrm{C} /\right.$ decade). This has lengthened the freeze-free season in many mid- and high-latitude regions. There are also indications that precipitation has increased by $0.5 \%-1 \% /$ decade in the 20th century over most mid and high latitudes of the Northern Hemisphere continents, and increased by $0.2 \%-0.3 \%$ /decade over the tropical land areas (IPCC 2001).

Owing to the complexity of the interactions between plants, animals, and their environment (Fig. 1), direct causal relationships are difficult to demonstrate and need long-term and detailed studies of ecological processes. However, biological systems quickly respond in a visible way to changes in the climate (Penuelas and Filella 2001; Walther et al. 2002). Many of these examples are changes in the timing of phenological stages, such as the date of first flowering, unfolding of the first leaf and the first bird migration, which are closely linked to climate (Ellis et al. 1997; Myneni et al. 1997; Walkovszky 1998; Ahas 1999; Crick and Sparks 1999; Menzel and Fabian 1999; Beaubien and Freeland 2000; Chmielewski and Roetzer 2000; Schwartz and Reiter 2000; Green et al. 2001; Menzel et al. 2001). The Third Assessment Report of the IPCC also recognised the importance of phenology. "Available observational evidence indicates that regional changes in climate, particularly increases in temperature, have already affected a diverse set of physical and biological systems in many parts of the world. Examples of observed changes include shrinkage of glaciers,

\footnotetext{
${ }^{1}$ See the websites of both the Dutch (http://www.natuurkalender.nl/) and the UK (http:www.phenology.org.uk/) networks
}

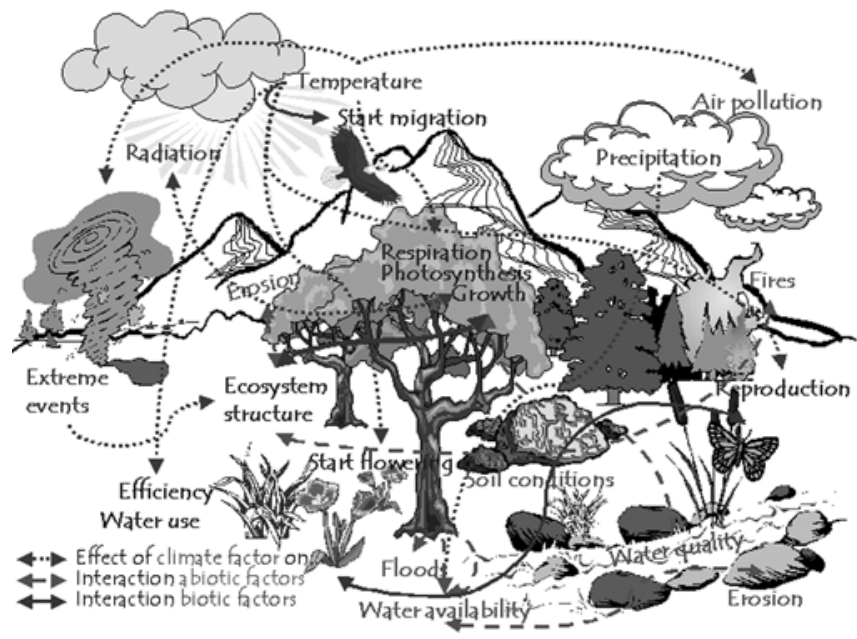

Fig. 1 Overview of the complexity of the many interactions between climate and biotic processes

thawing of permafrost, later freezing and earlier breakup of ice on rivers and lakes, lengthening of mid- to highlatitude growing seasons, pole ward and altitudinal shifts of plant and animal ranges, declines of some plant and animal populations, and earlier flowering of trees, emergence of insects, and egg-laying in birds" (Ahmad et al. 2001).

As natural systems respond quickly to changes in climate, it is becoming more important to assess potential future impacts under a continuously changing climate. The globally averaged surface temperature is likely to increase by $1.4-5.8^{\circ} \mathrm{C}$ over the period $1990-2100$ (IPCC 2001) affecting phenology to a large degree and causing a chain of reactions in both biological and social systems. Human society depends in many ways on the proper functioning of natural systems (e.g. Costanza et al. 1997) and climate-induced ecological changes will have a considerable impact on our society, notably through changes in agriculture, forestry, and human health. These impacts may be positive but more likely most will be negative, especially under the more rapid climate change scenarios (Houghton et al. 2001). Better information on the magnitude of ongoing and expected phenological changes is therefore crucial to allow balanced decisions to be made and appropriate adaptation and mitigation strategies developed.

\section{European Phenology Network}

To improve the use of phenological information in policy making as well as in research, there is an urgent need to expand research on, and monitoring of, phenological events, supported by better data collection protocols, storage systems and education and communication tools. In Europe, many professionals and volunteers are involved in phenological monitoring and research. Also, many long-term data sets exist, which provide important 
information on the relation between climate and natural systems. However, the efficiency of monitoring and use of phenological assessment in prediction of climateinduced ecological changes and their effects in Europe is surprisingly low. Some reasons for this are:

- No or only limited co-operation and communication between existing regional and national phenological monitoring networks in Europe.

- Lack of access to, and integration of data. This is partly caused by lack of information on what datasets are available, definitions and techniques used, and quality of the data.

- Inefficient use and exchange of existing knowledge within and between different scientific disciplines (ecology, agriculture, and human health) of tools and techniques already available for monitoring, data storage, and data analysis.

- Insufficient insight into, and awareness of the potential application possibilities of phenological data.

These problems were the basis for the formation of the European Phenology Network (EPN) (http://www.dow.wau.nl/msa/epn/. It is a so-called thematic network funded by the European Union, in which 13 partners from seven countries participate (see author list). EPN aims to "improve monitoring, assessment and prediction of climate induced phenological changes and their effects in Europe". Its overall objective is to increase the efficiency, added value and use of phenological monitoring and research, and to promote the practical use of phenological data in European member states in assessing the impact of global (climate) change and possible adaptation measures. More specific objectives of the Phenological Thematic Network are:

- To demonstrate the wide variety of possible applications of phenological research and its benefits for ecology, agriculture and society (human health and education) and achieve a stronger involvement of endusers

- To facilitate integration and co-operation between existing phenological monitoring networks, stimulate actively the expansion of existing networks and create new monitoring networks

- To improve the integration of, and access to phenological data in Europe in a systematic, structural and user-friendly way

- To exchange knowledge between phenologists of different scientific disciplines (ecology, agriculture, human health) on tools and techniques used for phenological monitoring, database development, (statistical) data analysis, model development, and impact assessment.

To realise these objectives, the activities of the EPN project are focussing on the:
1. Co-ordination of integration, co-operation and further expansion of phenological networks in Europe (including network management, clarifying the definitions used, establishing links with educational programmes, non-European networks, international organisations and potential funding organisations).

2. Establishment of an on-line phenological meta-database and a phenological bibliographical database.

3. Organisation of two European conferences on phenology involving data providers, scientists, (inter-)national non-governmental organisations, commercial enterprises, policy makers and educational organisations

4. Organisation of specialist workshops on specific topics (i.e. modelling, use of earth observation data, phenology and human health, phenology and agriculture, bird migration and communication, dissemination and capacity building).

The activities will result in increased communication and co-operation between researchers (within and across disciplines), private and public interest groups and decision makers (both corporate and governmental). Furthermore, data collected over a wide range of latitudinal, altitudinal and climatic conditions, linked through a common data base and network, will be much more generally applicable and can allow firmer conclusions to be drawn on the changes taking place, both natural and anthropogenic.

\section{Applications of phenology}

Changes in the timing of phenological events are relevant for many natural processes thereby influencing biodiversity. Our society, however, also depends on these natural processes, especially agriculture, forestry, and human health, which are influenced by changes in phenology in the context of climate change. Furthermore, changes in phenology play an important role in raising public awareness and education on the impacts of climate change. The following sections give a short overview of the range of applications involved, demonstrating the diversity of subjects involved and thus emphasising the need for co-operation and communication among the different actors involved.

\section{Consequences for biodiversity}

Biodiversity is defined by the Convention on Biological Diversity (CBD) as "the variability among living organisms from all sources including, inter alia, terrestrial, marine and other aquatic ecosystems and the ecological complexes of which they are part; this includes diversity within species, between species and of ecosystems" (http://www.biodiv.org/convention/articles.asp. The question is how changes in the timing of phenological events affect biodiversity. As shown in Fig. 1, interactions 
between climate and biotic processes are complex. Roughly three (or four) steps can be identified (partly after De Groot et al. 1995). Changes in timing of phenological events occur at the level of the individual organisms, affecting their productivity, reproduction and survival. In response to these changes at the individual and species level, many processes and feedback mechanisms at the ecosystem level will change (e.g. food chain dynamics or biogeochemical cycles). These changes may cause a chain of reactions that can lead to increased instability in ecosystems and atmosphere-biosphere interactions (Boer and De Groot 1990).

For example, an increase in temperature may cause a plant to flower earlier (van Vliet et al. 2002) or a bird to arrive earlier during the migration time. This change in behaviour has many consequences for the organism itself and for the entire ecosystem in which it lives. At the individual level, processes like transpiration, growth, health and reproduction change. As a result, the chances of survival of the organism are affected. If productivity and/or success of survival changes, many other organisms and processes in the whole ecosystem of which they are part will be affected. For example, Gallardo et al. (1998) demonstrated that the nutrient supply in several forests strongly depends on phenological factors.

A very important secondary impact of these direct changes is the change in interactions between species within an ecosystem through the food web such as competition, predation, parasitism and mutualism (Begon et al. 1990). For example, Both and Visser (2001) showed that the arrival date of the pied flycatcher (Ficedula hypoleuca), from overwintering in Central Africa, has not advanced while spring in their breeding grounds in the Netherlands has. Food availability for these birds has thus changed. A change in timing will also influence "mutualism" such as the pollination of plants by insects. Both the timing of insect appearance and flowering are often fine-tuned and the reproduction success of plants depends on the presence of insects (Marques Souza et al. 1993; Kato et al. 2000; Schiller et al. 2000). If species respond differently to a change in climate, consequences for the ecosystem are unavoidable and some species may become threatened or extinct (Both and Visser 2001). The combination of changes in species numbers and population sizes with a change in nutrient flow results in a change in ecosystem composition and ecosystem structure, which could lead to increased instability (De Groot et al. 1995). In addition to the impacts on biodiversity, changes in species composition and functioning of ecosystems will also influence biosphere-atmosphere interactions, and thereby climate. For example, vegetation plays an important role in determining the albedo of the earth's surface. It therefore directly influences the heat balance of the earth and thereby has a feedback effect on the rise in temperature through climate change. It furthermore influences evapotranspiration and thus precipitation in a given area. The uptake and release of greenhouse gases, such as carbon dioxide, by vegetation influences the total amount of greenhouse gases in the atmosphere and thereby climate change.

An important uncertainty in assessing the impact of climate change on biodiversity is whether species will be able to adapt to climate change. Many policy makers and scientists would like to determine a level of climate change under which no or limited impacts are expected and above which the ecological (and associated economic) damages are unacceptable. Here both, the rate of climate change $\left({ }^{\circ} \mathrm{C} /\right.$ year $)$ and the total change in climate are important. A critical level of $0.1{ }^{\circ} \mathrm{C} /$ decade is often used as a change to which many species can adapt to with a maximum "total" increase in temperature of $2.0{ }^{\circ} \mathrm{C}$ (Swart et al. 1998). It is important that the phenological community contributes to this discussion. Many phenologists would stress that it is very difficult or even impossible to assign such a level. Species have always adapted to their local climate and their current life cycle is a result of this process. It is, however, quite difficult to determine the time needed for species to adapt.

Many fundamental questions in ecological responses of climate change can be addressed by phenological research as it is already focused on a large number of issues that are relevant to interactions between climate and ecological systems. It is important to note that interannual variation in climate has always been very high. Species have always responded differently to this and insight into the phenological characteristics of the species involved has always been required.

\section{Forestry}

The effects of changes in the length of growing season have also clearly been acknowledged for forest areas. Remote sensing studies, for example, have indicated that net primary productivity in forests of the Northern Hemisphere has substantially increased (Myneni et al. 1997; Zhou et al. 2001). It is believed that this is caused by the increase in temperature, which influences both the length of the growing season and growth itself. Changes in forest productivity are directly relevant from an economic perspective because they influence the wood production of forests. However, in the context of the Kyoto protocol, the contribution of forests to carbon sequestration has also become of economic relevance.

Therefore information on potential changes in the timing of phenological events is relevant for many forest management activities. Another important issue that directly influences forest management is the occurrence of pests and diseases. Fleming and Candau (1998) demonstrated that insect outbreaks are a major disturbance factor in Canadian forests. Substantial changes in distribution of pests, the resulting increase in vulnerability for forest fires, and the changing rates of biogeochemical cycling are some of the drivers of this disturbance.

The recent increase in temperature in Europe has resulted in a change in the distribution of the gypsy moth (Lymantria dispar) as well as an increase in its develop- 
ment rate. The gypsy moth has ravaged about 10,000 ha of oak forest in Baden (southern Germany), as well as corn, strawberry and asparagus fields. In Austria, between 1,500 and 2,000 ha of oak forests are infested, and the Lymantria caterpillars have completely denuded all leaves on infested trees (Greenpeace Climate Impacts Database 2002). Another example is the outbreak of Dendrolimus sibirica in East Siberia between 1994 and 1997. This outbreak caused the death of highly productive dark coniferous forests in an area exceeding 1.2 million ha (Shvidenko et al. 1998).

We should be aware that, in addition to climate, other factors might influence phenological changes. The availability of nutrients, for example, influences the duration of the growing season for some species. A study by Karlsson and Nordell (1989) demonstrated that growth of Pinus trees did not change with nutrient supply while growth and duration of foliage for Betula increased with increasing nutrient supply. Temperature affects foliage growth of Pinus during spring but not in autumn, whereas, for Betula, temperature conditions during the whole growth period are important for determining the seasonal production of foliage.

Effects of elevated $\mathrm{CO}_{2}$, clone types and plant nutrition on bud dormancy of Sitka spruce [Picea sitchensis (Bong.) Carr.] were examined by Murray et al. (1994). One of their conclusions was that increasing plant nutrient supply lengthened the growing season; plants flushed earlier in the spring and set bud later in the autumn. However, elevated $\mathrm{CO}_{2}$ delayed bud burst in the spring and advanced bud set in the autumn. An important conclusion was also that there was a large natural variation in the timing of bud burst and bud set among different clones. Elevated $\mathrm{CO}_{2}$ had no effect on bud dormancy of the Skidegate a clone, but it reduced the growing season of the North Bend b clone by 20 days.

\section{Agriculture}

A great deal of the historical interest in the phenology of plants stems from an interest in the performance of agricultural crops and its relation to local climate. Indeed, many phenological monitoring networks were established with agricultural purposes in mind, as it was clear that, following observation of (wild) plants and animals, something could be said about the climate and the suitability for agricultural crops. The likely effects of climate change have renewed this interest and predictions of the future suitability of production areas for a given crop are of great interest again. A classic example is the likely change in production areas for grapevines (Kenny and Harrison 1993; Bindi et al. 1996; Jones and Davis 2000) which may be extended to the north and even more to the east of current production areas in Europe. Phenological information is also required for the parameterisation of plant growth models describing developent of the quantity and possibly the quality of main agricul- tural crops such as wheat and the likely impact of climate change (Harrison et al. 2000).

With the wide acceptance of integrated pest management in today's agricultural production, the interaction between pest/disease and crop development has become a major focus of research activities worldwide. And how is the relation between developmental rates of pests/diseases and crops affected? Many pests quickly respond to climate variability. An increase of the mean spring temperature by $1{ }^{\circ} \mathrm{C}$ can cause aphids to emerge from 4 to 19 days earlier, depending on the species (Zhou et al. 1995). The rate of development also increases, which increases their chances of survival and an increase in population densities. On the other hand, crop development is also enhanced but with different effects possibly causing problems. Pest management activities should thus be focused on the impact of climate change on the development of pests and diseases in relation to plant development. The complexity of the issue is also demonstrated by Butts and Lambs (1991). They found that the seeding date of oilseed rape influenced the abundance of lygus bugs such that the highest densities were found in the crops that reached the bud stage earliest. Lygus bugs are a potentially serious pest of oilseed rape because their phenology ensures that laterinstar nymphs and adults are present in the crop when seeds are developing.

\section{Human health}

Despite the significant improvement in our understanding the impacts of climate change on health in the last decades, the complete range of these is still difficult to understand effects. McMichael et al. (1996) have classified the effects of climate change into directly acting effects (e.g. heat-wave-related deaths, weather disasters) and others that will result from disturbances to complex ecological processes (e.g. changes in patterns of infectious disease, in freshwater supplies, and in food availability).

The ecology and dynamics of infectious diseases are very complex and unique for each disease in each locality (McMichael and Githeko 2001). With regard to human infectious diseases, there is still very little information available on the impacts of climate change and most studies have been undertaken with respect to vector-borne diseases. Weather and climate affect vector population dynamics and disease transmission in various ways, with temperature and humidity considered key variables. Only recently have researchers attempted to understand how climate variability might affect the distribution of vectorborne diseases. Direct effects of changes in regional temperature, precipitation, humidity and wind patterns are climate parameters that should have an impact on the vectors' reproduction, development rate and longevity, and the rate of development of a parasite. Indirect effects of climate variability would include variability in vegetation coverage, agricultural practices, drought and 
floods. The large-scale migration of populations from areas in which vector-borne diseases are endemic into receptive areas could also prove significant. It would be interesting to understand better the relationship between climate and the phenology of infectious diseases in general. Scientific results and practical tools (models/ scenarios) from ecological and agricultural studies that focus on phenology might be of interest to those people and organisations that work on assessing the distribution of vector-borne diseases.

A much clearer aspect and also a focal point of EPN is the forecasting of allergenic pollen flow. The human population is exposed to outdoor allergens, which cause seasonal allergic rhinitis or hay fever. Therefore, the timing and duration of the flowering season, and thus pollen flow, are of great interest to all those having to deal with allergic reactions to pollen, but also for the medical industry as they have to have vaccines ready on time. Evidence is mounting that especially the onset of seasons is more advanced (Menzel and Fabian 1999). Pollens that are light enough to be wind-borne cause the problem for most hay-fever sufferers. Heavier pollens that are carried from plant to plant by bees and by other insects can also be allergens, but they only cause trouble when a person comes into direct contact with the plant. Airborne pollens can penetrate anywhere, indoors and out, and are most numerous at the height of the pollinating season for the particular plant. Between $3 \%$ and $31 \%$ (depending on country) of the European population suffer from allergies (D'Amato et al. 1998). In the United Kingdom, pollen from trees such as the silver birch, ash, oak and London plane are most likely to cause early spring problems. In addition, grass species such as timothy, rye, cocksfoot, meadow and fescue pollinate during mid-summer from May to August. The start of the pollen season varies greatly from year to year. For example, the start of the grass pollen season in Britain can differ by about 32 days according to the weather in spring and early summer http://pollenuk.worc.ac.uk/aero/AP.html. Van Vliet et al. (2002) studied the influence of a recent temperature rise in the Netherlands on the start of the pollen season. They found that the start of the pollen season took place 23 days earlier in the warm 1990s than in the colder 1970s. The differences between years will potentially increase even more with the expected climate change. Therefore models forecasting the pollen season are needed.

\section{Raising public awareness and education}

During the last 5 years there has been a strong increase in interest in phenology, and not only from the scientific point of view; thousands of volunteer recorders from the general public have joined existing and new phenological monitoring networks (Whitfield 2001). This is partly due to the significant changes in timing of life-cycle events, which are easily visible to the public. On the other hand there has been a substantial role for the media. The press find it easy to understand the observed changes and, in several countries, they have successfully communicated the changes in timing to the wider public. Many newspaper articles, radio programmes, and television programmes have paid attention to the changes observed. The developments in the UK and The Netherlands clearly illustrate the role of the media. The start of EPN was the reason for the National Radio programme VARA's Vroege Vogels (Early Birds) to participate in reviving the phenological network in The Netherlands under the name De Natuurkalender (Nature's Calendar) (http:// www.natuurkalender.nl/). Every Sunday morning a few minutes is spent on the results of the previous week. About half a million people listen to this programme. Over a few weeks more than 2000 people registered to participate. Since the start of EPN and De Natuurkalender over 50 newspaper articles in The Netherlands and ten national television programmes have dealt with phenology. In the United Kingdom the media, particularly the BBC weather broadcasts, have also played a significant role in publicising the phenological network Nature's Calendar (http://www.phenology.org.uk/). In less than 2 years over 10,000 people registered to participate in the monitoring programme.

It is becoming clear that people enjoy participating in these kind of large-scale initiatives, which are linked to global environmental issues like climate change. Phenology has proven able to communicate the difficult issue of climate change to the public and to demonstrate that changes are visible in their own backyard. This provides many opportunities for phenological monitoring and research as national and international interest in communication, education and information related to the issues of climate change and biodiversity is increasing rapidly. Both the Convention on Biological Diversity (CBD) and the United Nations Framework Convention on Climate Change (UNFCCC) stress the importance of this issue.

One group of the public on which EPN focuses its attention is school children. Many different educational projects already exist in which schools are involved in making observations of their environment and many of them include phenological observations ${ }^{2}$ (van Yperen et al. 2002). EPN will recognise the link between education and phenology via participation in the GLOBE programme (Global Learning and Observations to Benefit the Environment). This organisation is a worldwide network of students, teachers and scientists working together to study and understand the global environment. Students and teachers from over 11,000 schools in 98 countries are working with research scientists to learn more about our planet. The GLOBE programme is implemented via the national governments and school bodies in these countries. Students make environmental observations at or near their schools on the basis of detailed protocols and report their data through the Internet. Scientists use the data in their research and provide feedback to the students to enrich their science education. Global images based on

\footnotetext{
${ }^{2}$ The GLOBE programme, Natur-detektive, Natuurkalender, Plantwatch, Baltic Sea Project, Ecological Co-operation
} 
student data are displayed on the World Wide Web, enabling students and other visitors to visualise the student environmental observations.

Within EPN we will focus on a number of activities. First of all, we will make an inventory of requirements to integrate the different networks and of the potential problems that might arise. We will also try to adjust phenological observation protocols and educational materials; the project will adapt the phenological protocols and education materials used outside Europe to the European situation. An initial version of the report will be evaluated by several schools and afterwards adjusted. After this activity, EPN will identify a number of schools that can participate in the programme. Finally, EPN will establish links with scientists, as the involvement of scientists in the programme is an important aspect of GLOBE.

\section{Integration and co-operation of existing observing systems}

The large number of already existing long-term phenological observation data sets and networks offer great potential for analyses and quantification of the impact of climate change and its effects on a wide range of issues concerning ecology, agriculture, forestry and human health. However, to use the data from the different countries effectively, integration of and co-operation between the existing networks are required. There are a number of issues that have to be addressed. As most of these networks have their own history, they often use different definitions of flowering, leaf unfolding or leaf fall, for example. Observations on starting dates of flowering from one network cannot easily be compared with the observations from another network. Different networks also have different species in the monitoring programme and it is highly likely that the variety of species differs from network to network. The training and instruction of network personnel also vary substantially as they may be volunteers or professionals. Some networks use pre-selected observation sites while, in others, the location of sites differs from year to year. Furthermore, there are differences in data gathering and data processing. This all results in large differences in the quality of the data.

EPN aims to achieve integration, co-operation and expansion by reaching agreement on the international standardisation of monitoring programmes. Standardising of phenophase definitions would be beneficial but probably impossible, as long-standing networks will have difficulties with changing their definitions. One way to overcome this is by introducing a coding system, which expresses the degree of similarity of a definition compared with a standard list of definitions. A suggested standard list is the $\mathrm{BBCH}$ coding system (Meier et al. 1994), which has evolved through the need to define the growth stages of a whole range of agricultural and horticultural crops so that experiments with chemical sprays can be compared worldwide. However, it is equally suitable for all other plant and possibly animal species. This system will make it possible to determine whether or not phases can be compared with each other.

Another way to improve the integration of networks is by setting up a network of phenological gardens in which a small number of carefully selected, genetically identical species could be planted and monitored. The timing of phenophases can then be compared and function as some sort of backbone observations via which the results of local or national networks can be linked together.

One such initiative, the International Phenological Gardens (IPG), has been operational in Europe since 1959 (http://www.agrar.hu-berlin.de/pflanzenbau/agrarmet/ ipg_1.html). In addition, a new network, Global Phenological Monitoring, has been established, which can encompass a large part of the world and facilitate comparison of results worldwide. The first gardens have already been established in Germany, The Netherlands, China, USA, Slovakia, and Estonia. Such an international network is greatly enhanced through observations on common species. There are a number of species that are included in the majority of monitoring networks in Europe (e.g. horse chestnut (Aesculus hippocastanum), wood anemone (Anemone nemorosa), and swallows (Hirundo rustica)). EPN will identify other shared species and start discussions on how co-operation may be established.

\section{Integration of and access to phenological information}

As many phenological networks exist or have existed in the past, a lot of data and information are potentially available for further research. These data are not only very valuable for future scientific research but also provide communication and information to the general public (climate change needs to be interpreted in the context of natural climate variability). Within EPN the need for improving access to, and information on, the data that exist is clearly recognised. EPN will create both an on-line metadatabase (http://www.pik-potsdam.de/ rachimow/epn/html/) and an on-line bibliographical database. By establishing a phenological metadatabase, a continuous overview will be provided of what phenological networks and data are available. This overview will significantly increase the access to, and exploitation of these data for a large range of disciplines (e.g., ecology, agriculture, human health, and earth observation). In addition to improving data access, and information on data availability, information on recent and historic scientific results and methods is also of crucial importance for effective exploitation of existing data. EPN will greatly contribute to the more efficient use of scientific research by creating an on-line central bibliographical database. The on-line databases will function as a central point during the EPN project and certainly after the project ends. 


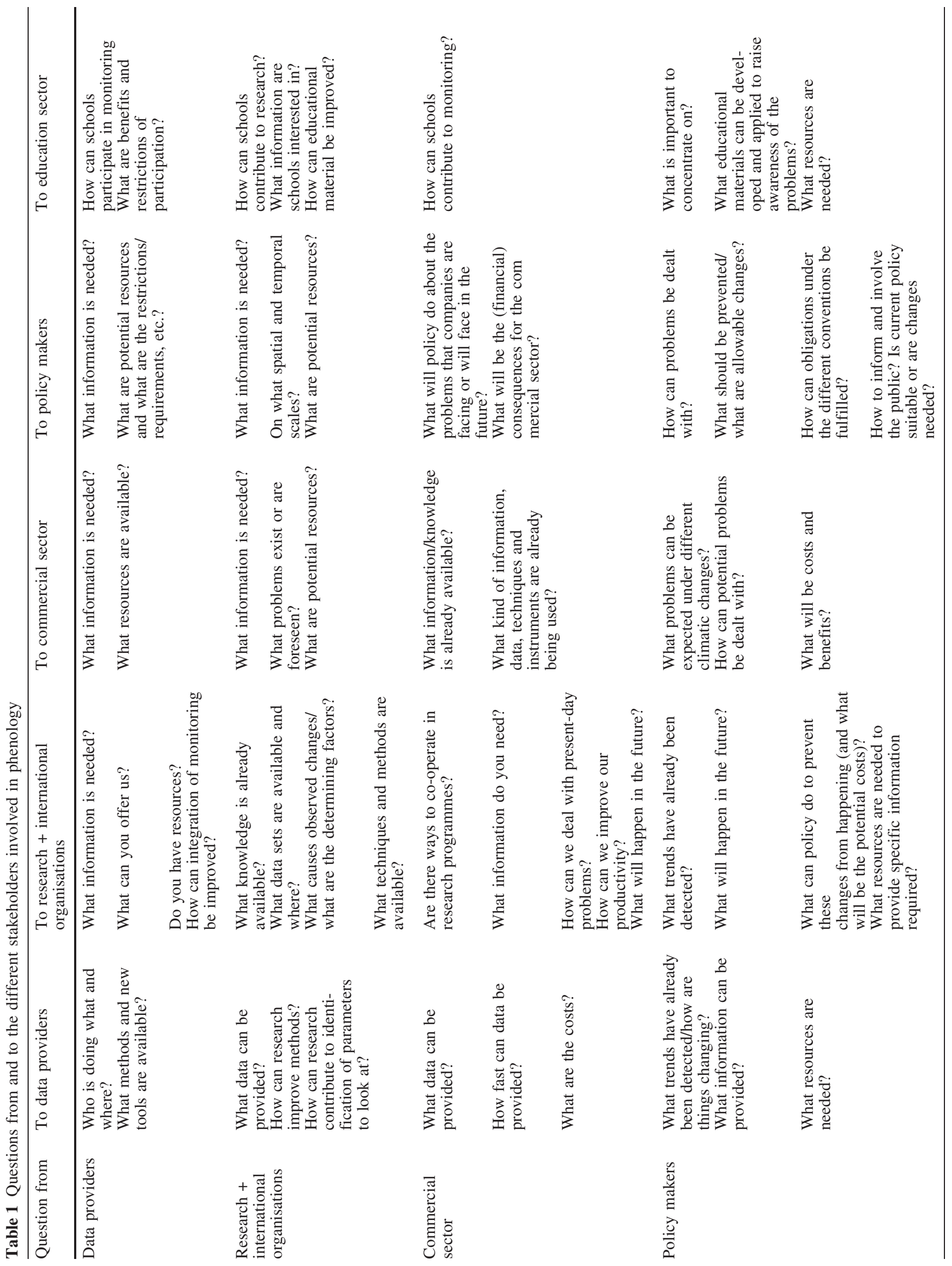


A further step would be to go beyond the metadatabase by creating an international phenological database, which contains real phenological data. The database should be constructed in such a way that those who are willing to provide access to their own data can add to the phenological database.

\section{Communication}

To examine the complex issues discussed in the previous paragraphs, increased collaboration is needed to ensure that countries and disciplines are not working independently and duplicating one another's efforts. Data collected over a wider range of latitudinal, altitudinal and climatic conditions have general applicability and allow firmer conclusions to be drawn on the environmental changes, natural and anthropogenic, taking place.

The European Phenology Network provides a unique opportunity for the phenological community to meet and discuss areas of phenological research, and a large number of meetings are being organised. Two phenological conferences will function as the main integration tools and address as many issues as possible by bringing together representatives of all those involved in phenological research and monitoring and the use of phenological data. The two conferences are also very important in providing input in EPN activities aimed at network development, databases and workshops. Participants will have the opportunity to present their own research and interests, to learn new techniques, to discuss specific issues and to meet potential new partners. These conferences provide a complete overview of the many different potential uses and applications of phenological data, especially in relation to global (climate) change issues.

On a number of subjects it is, however, more efficient to have separate specialist workshops in which a small number of experts are involved, as discussions will go into more detail than would be possible at larger meetings. Issues involved are modelling, use of earth observation data, human health, agriculture and economic consequences, bird migration, and communication dissemination and capacity building. Table 1 provides the first overview of the need for communication between the different user groups involved, demonstrating the large range of questions still needing to be answered.

\section{Conclusions and discussion}

In this paper we have tried to make clear that it is increasingly being recognised that phenological records provide an integrative indication of the sensitivity of natural systems to climate change and have a high value in climate impact assessment studies (both of past changes and future impacts). We have also demonstrated that changes in phenological events have large consequences for biodiversity, agriculture, forestry, and human health, making phenology a valuable generic indicator of 
changes in ecological and human systems. Furthermore, phenological changes are often easy to observe, which makes them an efficient tool in studies on the impact of climate change. Thus, phenology already contributes significantly to the global change debate, but there is also much more potential for future contributions. However, in order to make use of this potential, the study of phenology has to be developed further. The European Phenology Network was born out of a realisation that we face a large number of challenges and tries to address many of these challenges by focusing on scientific issues and on communication, co-operation, education and data exchange. With EPN we do not aim to solve all problems and answer all questions but we do aim to make a significant contribution.

Many scientific studies have demonstrated the role of climate in the observed changes in the timing of phenological events in the last century. However, even though quite a number of examples are already available, for many species information on climate sensitivity is still scarce. Even if it is already clear how certain species respond to a change in temperature, more information is needed from various regions for a reliable assessment to be made of the potential future impacts of climate change on the timing of phenological events in various taxonomic groups and in different regions. The EPN makes it clear that it is important to stress the large number of disciplines involved in phenological research and that many questions are still unanswered. From the biodiversity perspective we need to know whether and how species can adapt to the expected changes in climate (is their genetic and phenological flexibility large enough) and how the (a)biotic environment (e.g. soil, nutrient availability, radiation, $\mathrm{CO}_{2}$ concentration) in a given ecosystem will be influenced. The latter are often not taken into account in studies of the impact of climate change while they might be very relevant.

In addition, it is important to develop mitigation and adaptation strategies. Do farmers and forest managers have to consider the use of new varieties that are better adapted to the new situation and will they be confronted with more and new pests and diseases? And how should they respond? On the basis of what assumptions can these decisions be made? How does the length of the growing season influence allergenic pollen flow? In order to find answers to these questions, co-operation between those with different expertise (phenologists, aerobiologists, health personnel) should be improved.

Many of these issues, however, are not specifically linked to disciplines involved with phenology. Within the global change community many networks and disciplines have dealt, or are currently dealing, with many of the issues described. Closer involvement of phenologists in the global change community is therefore required. With the strong increase in interest, the different communities are coming closer but there can still be substantial improvement. EPN will try to facilitate the linkage and the co-operation between the phenology community and the global change community.

\section{References}

Ahas R (1999) Long-term phyto-, ornitho- and ichthyophenological time-series analyses in Estonia. Int J Biometeorol 42:119-123

Ahmad QK, Anisimov O, et al (2001) Summary for policymakers. Climate change 2001: impacts, adaptation, and vulnerability. A report of Working Group II of the Intergovernmental Panel on Climate Change. IPCC, Geneva, p 17

Beaubien EG, Freeland HJ (2000) Spring phenology trends in Alberta, Canada: links to ocean temperature. Int J Biometeorol 44:53-59

Begon M, Harper JL, Townsend CR (1990) Ecology; individuals, populations and communities. Blackwell, Boston, p 945

Bindi M, Fibbi L, Gozzini B, Orlandini S, Miglietta F (1996) Modelling the impact of future climate scenarios on yield and yield variability of grapevine. Clim Res 7:213-224

Boer MM, De Groot RS (eds) (1990) Landscape-ecological impact of climatic change. In: Proceedings of a European conference, Lunteren, The Netherlands, 3-7 December 1989. IOS Press, Amsterdam, p 429

Both C, Visser ME (2001) Adjustment to climate change is constrained by arrival date in a long-distance migrant bird. Nature 14:296-298

Butts RA, Lambs RJ (1991) Seasonal abundance of three Lygus species (Heteroptera: Miridae) in oilseed rape and alfalfa in Alberta (Canada). J Econ Entomol 84:450-456

Chmielewski FM, Roetzer T (2000) Phenological trends in Europe in relation to climatic changes. Agrarmeteorol Schr Heft 07:15

Costanza R, D'Arge R, Groot RSd, Farber S, Grasso M, Hannon B, Limburg K, Naeem S, O’Neill RV, Paruelo J, Raskin RG, Sutton P, Belt M (1997) The value of the world's ecosystem services and natural capital. Nature 387:253-260

Crick HQP, Sparks TH (1999) Climate change related to egg-laying trends. Nature 399:423-424

D’Amato G, Spieksma FTM, Liccardi G, Jäger S, Russo M, Kontou-Fili K, Nikkels H, Wüthrich B, Bonini S (1998) Pollenrelated allergy in Europe. Allergy 53:567-578

De Groot RS, Ketner P, Ovaa AH (1995) Selection and use of bioindicators to assess the possible effects of climate change in Europe. J Biogeogr 22:935-943

Ellis WN, Donner JH, Kuchlein JH (1997) Recent shifts in phenology of Microlepidoptera, related to climatic change (Lepidoptera). Entomol Ber 57:66-72

Fleming RA, Candau JN (1998) Influences of climatic change on some ecological processes of an insect outbreak system in Canada's boreal forests and the implications for biodiversity. Environ Monit Assess 49:235-249

Gallardo JF, Martin A, Regina IS (1998) Nutrient cycling in deciduous forest ecosystems of the Sierra de Gata mountains: aboveground litter production and potential nutrient return. Ann Sci For (Paris) 55:749-769

Green RE, Harley M, Spalding M, Zockler C (2001) Impacts of climate change on wildlife. RSPB, Cambridge, p 71

Greenpeace Climate Impact Database (2002) Acces date 03-072002 http://archive.greenpeace.org/climate/database/records/ zgpz0483.html

Harrison PA, Porter JR, Downing TE (2000) Scaling-up the AFRCWHEAT2 model to assess phenological development for wheat in Europe. Agric For Meteorol 101:167-186

Houghton JT, Ding Y, Griggs DJ, Noguer M, Van der Linden PJ, Xiaosu D (2001) Climate change 2001: the scientific basis. Contribution of Working Group I to the Third Assessment Report of the Intergovernmental Panel on Climate Change (IPCC). Cambridge University Press, Cambridge, p 944

IPCC (2001) Summary for policymakers; A report of Working Group I of the Intergovernmental Panel on Climate Change. IPCC, Shanghai, p 18

Jones GV, Davis RE (2000) Using a synoptic climatological approach to understand climate-viticulture relationships. Int J Climatol 20:813-837

Karlsson PS, Nordell KO (1989) Effects of leaf duration, nutrient supply, and temperature on the seasonal pattern of growth and 
nitrogen uptake in tree seedlings in a subarctic environment. Can J Bot 67:211-217

Kato M, Itioka T, Sakai S, Momose K, Yamane S, Hamid AA, Inoue T (2000) Various population fluctuation patterns of lightattracted beetles in a tropical lowland dipterocarp forest in Sarawak. Popul Ecol 42:97-104

Kenny GH, Harrison PA (1993) The effects of climatic variability and change on grape suitability in Europe. J Wine Res 4:163183

Marques Souza AC, Absy ML, Afonso P, Conde A, De Alencar Coelho H (1993) Data on pollen collection by workers of Apis mellifera in the municipality of Ji-Parana (RO), Brazil. Acta Amazonica 23:59-76

McMichael AJ, Ando M, Carcavallo R, Epstein P, Haines A, Jendritzky G, Kalkstein L, Odongo R, Patz J, Piver W (1996) Human population health. In: Climate change 1995. Impacts, adaptations, and mitigation of climate change: scientifictechnical analyses. Contribution of Working Group II to the Second Assessment Report of the Intergovernmental Panel on Climate Change. Cambridge University Press, Cambridge, pp 561-584

McMichael AJ, Githeko A (2001) Human health. In: McCarthy JJ, Canziani OF, Leary NA, Dokken DJ, White KS (eds) Climate change 2001. Impacts, adaptation, and vulnerability. Cambridge University Press, Cambridge, pp 451-487

Meier U, Graf H, Hack H, Heß M, Kennel W, Klose R, Mappes D, Seipp D, Strauß R, Streif J, Boom T van den (1994) Phänologische Entwicklungsstadien des Kernobstes (Malus domestica Borkh. und Pyrus communis L.), des Steinobstes (Prunus-Arten), der Johannisbeere (Ribes-Arten) und der Erdbeere (Fragaria $\times$ ananassa Duch.) - Codierung und Beschreibung nach der erweiterten BBCH-Skala. Nachrichtenbl Dtsch. Pflanzenschutzdienst (Berl) 46:141-153

Menzel A, Fabian P (1999) Growing season extended in Europe. Nature 397:659

Menzel A, Estrella N, Fabian P (2001) Spatial and temporal variability of the phenological seasons in Germany from 19511996. Global Change Biol 7:657-666

Murray MB, Smith RI, Leith ID, Fowler D, Lee HSJ, Friend AD, Jarvis PG (1994) Effects of elevated CO-2, nutrition and climatic warming on bud phenology in Sitka spruce (Picea sitchensis) and their impact on the risk of frost damage. Tree Physiol 14:691-706
Myneni RB, Keeling CD, Tucker CJ, Asrar G, Nemani RR (1997) Increased plant growth in the northern high latitudes from 1981 to 1991. Nature $386: 698-702$

Penuelas J, Filella I (2001) Responses to a warming world. Science 294:793-794

Schiller JR, Zedler PH, Black CH (2000) The effect of densitydependent insect visits, flowering phenology, and plant size on seed set of the endangered vernal pool plant Pogogyne abramsii (Lamiaceae) in natural compared to created vernal pools. Wetlands 20:386-396

Schwartz MD, Reiter BE (2000) Changes in North American spring. Int J Climatol 20:929-932

Shvidenko A, Nilsson S, Stolbovoi V, Wendt D (1998) Background information for carbon analysis of the Russian forest sector. International Institute for Applied Systems Analysis, Laxenburg, p 125

Swart R, Berk M, Janssen M, Kreileman E, Leemans R (1998) The safe landing approach: risks and trade-offs in climate change. In: Alcamo J, Leemans R, Kreileman E (eds) Global change scenarios of the 21st century; results from the IMAGE 2.1 model. Elsevier, Oxford, pp 193-218

Vliet AJH van, Overeem A, De Groot RS, Jacobs AFG, Spieksma FTM (2002) The influence of temperature and climate change on the timing of pollen release in The Netherlands. Int $\mathbf{J}$ Climatol 22:1757-1767

Yperen M van, Bellens Y, Tasker A (2002) Requirements for linking educational phenological networks. GLOBE Europe, SME/Institute for Environmental Communication, Utrecht, p 78

Walkovszky A (1998) Changes in phenology of the locust tree (Robinia pseudoacacia L) in Hungary. Int $\mathrm{J}$ Biometeorol 41:155-160

Walther G-R, Post E, Convey P, Menzel A, Parmesan C, Beebee TJC, Fromentin J-M, Hoegh Guldberg O, Bairlein F (2002) Ecological responses to recent climate change. Nature 416:389-395

Whitfield J (2001) The budding amateurs. Nature 414:578-579

Zhou XL, Harrington R, Woiwod IP, Perry JN, Bale JS, Clark SJ (1995) Effects of temperature on aphid phenology. Global Change Biol 1:303-313

Zhou L, Tucker CJ, Kaufmann RK, Slayback D, Shabanov NV, Myneni RB (2001) Variations in northern vegetation activity inferred from satellite data of vegetation index during 1981 to 1999. J Geophys Res 106:20,069-20,083 